\title{
Effects of dietary total sulphur amino acids to lysine ratio on performance, nitrogen utilization of Ac layers (black-boned chicken)
}

\author{
T.V. Phuoc ${ }^{1}$, N.N.X. Dung ${ }^{2 \#}$ \& L.H. Manh ${ }^{2}$ \\ ${ }^{1}$ Department of Animal Husbandry and Veterinary Medicine, College of Agriculture and Food Technology, Tien Giang \\ University, Vietnam \\ ${ }^{2}$ Department of Animal Sciences, College of Agriculture, Cantho University, 3/2 Street, Cantho City, Vietnam
}

(Received 18 August 2018; Accepted 28 January 2019; First published online 18 March 2019)

\author{
Copyright resides with the authors in terms of the Creative Commons Attribution 4.0 South African Licence. \\ See: http://creativecommons.org/licenses/by/4.0/za \\ Condition of use: The user may copy, distribute, transmit and adapt the work, but must recognise the authors and \\ the South African Journal of Animal Science.
}

\begin{abstract}
A study was conducted to evaluate the effects of dietary total sulphur amino acids (TSAA) to lysine (Lys) ratio on performance of Ac layers (black-boned chicken). A total of 800 laying hens from 38 to 50 weeks old was allocated according to a completely randomized design with five treatments and 20 replicates of 8 birds each. The basal diet was formulated with $16 \%$ crude protein (CP), $2755 \mathrm{kcal} / \mathrm{kg}$ of metabolizable energy (ME), $0.482 \%$ methionine, $0.925 \%$ TSAA and $1.12 \%$ lysine. The TSAA/Lys ratio of the basal diet was 0.85. The basal diet plus four diets were formulated, two with TSSA levels at $10 \%$ and $20 \%$ below and two at $10 \%$ and $20 \%$ above that of the basal diet, giving $0.762 \%, 0.857 \%, 1.047 \%$ and $1.142 \%$ TSAA, respectively with the basal at $0.925 \%$ TSAA. The $10 \%$ decrease or increase in TSAA from $0.952 \%$ did not affect feed intake or egg production. However, further TSAA decreases from $0.857 \%$ to $0.762 \%$ led to reducing egg weight, which increased with a curvilinear trend as the level of TSAA in the diets was increased. TSAA influenced nitrogen retention in a quadratic trend, with hens fed diets containing $0.952 \%$ and $1.047 \%$ TSAA retaining more nitrogen than the other treatments. Increasing dietary TSAA increased the white and yolk index and Haugh unit, whereas egg shell thickness, yolk colour and egg components were not influenced. The TSAA/Lys ratio of 0.85 improved egg weight and nitrogen retention of Ac layers.
\end{abstract}

Keywords: Egg weight, feed intake, performance, production, nitrogen retention, sulphur amino acid

\# Corresponding author: nnxdung@ctu.edu.vn

\section{Introduction}

Ac chicken is a native black-boned breed that is characterized by white feathers, skin, meat and bones, which is kept in the Mekong Delta of Vietnam. This breed has a small body size $(0.9 \mathrm{~kg})$, and is kept for meat and egg production. The Ac chicken has potential in meat and egg production because of its good flavour and relatively high price. Like other indigenous breeds, the growth performance and egg production of Ac chicken are low compared with those of commercial breeds. However, the consumption of Ac chicken meat and eggs has grown in Vietnam, particularly in Ho Chi Minh City. According to Phuong \& Thien (2008), because they are kept in a scavenging system, Ac egg production is low with $90-95$ eggs/year, though it could be improved to 180 - 190 eggs/year (Phuoc et al., 2016a) by providing good nutrition and disease control.

Non-ruminant animals have specific requirements for the amino acid, lysine (Han \& Baker, 1991; Baker et al., 2002). The important role of lysine has been indicated by NRC (1984) and is considered a 'reference amino acid', and other essential amino acids are related to the percentage of lysine in diet formulation for pigs and poultry to maintain the balance among amino acids. Cereals such as maize and soybean are low in lysine (D'Mello, 1993) and methionine content (Waibel et al., 1995), but are used as main feed ingredient sources of poultry diets. Lysine is necessary for synthesis and improving protein deposition (Tesseraud et al., 1992) and changes metabolism in chicken (Tesseraud et al, 1996). Improved lysine intakes increased the final weight and carcass weights of broilers (Kidd \& Flancher, 2001) and broiler chicks (Kidd et al., 1998), and enhanced the meat yield of Chinese local chicken (Yuan et al., 2015). High 
methionine intakes improved egg production (Harms \& Russell, 2003) and increased egg weight (Sohail et al., 2002).

Many studies have been conducted on the nutrient requirements of poultry, and the need for essential amino acids such as lysine and methionine for laying hens has been pointed out (NRC, 1994; Leeson \& Summers, 2005). However, information on protein, energy and amino acid requirements of Ac hens is limited.

Phuoc et al. (2016a, 2017) reported that a dietary protein level of $160 \mathrm{~g} / \mathrm{kg}$ and $2700 \mathrm{kcal} / \mathrm{kg}$ of feed enhanced egg weight and egg mass of Ac hens in confinement. For commercial laying hens the requirements for lysine and methionine + lysine have been studied extensively, but few studies have been done using Ac hens. Judicious supplementation of amino acids for hens is one way to reduce dietary protein levels, decrease excreta nitrogen $(\mathrm{N})$ and improve production performance.

Therefore, the aims of this study were to evaluate the effects of five ratios of TSAA/lysine (TSAA/Lys), at $10 \%$ and $20 \%$ lower and $10 \%$ and $20 \%$ higher than the NRC (1994) recommendations, on productivity, nutrient digestibility and $\mathrm{N}$ utilization of Ac hens from 38 to 50 weeks old.

\section{Materials and Methods}

This study was carried out for 10 weeks in Tien Giang Province. Eight hundred Ac layers $(0.9 \pm 0.05$ $\mathrm{kg}$ ) in an opened-side house were used in a completely randomized design. Diets were formulated on an available amino acid basis. The recommendation for TSAA/Lys (NRC 1994) in the diet is $0.85 \%$, in which TSAA and lysine were $0.962 \%$ and $1.12 \%$, respectively (Phuoc et al., 2018). The experiment consisted of five dietary treatments, which varied in TSAA/Lys ratios of $0.73 \%, 0.81 \%, 0.85 \%, 0.89 \%$ and $0.94 \%$, with 20 replicates. One hundred cages with drinkers and troughs were randomly allocated to the five treatments with eight birds per each.

Table 1 Diet formulation and composition of basal diet of experimental Ac laying hens

\begin{tabular}{|c|c|c|c|}
\hline $\begin{array}{l}\text { Ingredients } \\
\text { (\%) }\end{array}$ & $(g / k g)$ & $\begin{array}{l}\text { Nutrient composition } \\
\text { (air dry basis) }\end{array}$ & $\%$ \\
\hline Maize & 485.0 & Dry matter & 89.77 \\
\hline Wheat bran & 133.3 & Ash & 11.35 \\
\hline Rice bran & 65.0 & Crude protein & 16.04 \\
\hline Fish meal & 28.0 & Crude fat & 4.37 \\
\hline Soybean meal & 181.3 & Crude fibre & 3.00 \\
\hline Tra fish oil & 10.0 & Neutral detergent fibre & 13.44 \\
\hline Coarse limestone & 38.0 & Calcium & 4.07 \\
\hline Fine limestone & 40.0 & Phosphorus & 0.67 \\
\hline Di-calcium phosphate & 8.40 & Lysine & 1.12 \\
\hline Premix minerals ${ }^{1}$ & 2.50 & Methionine & 0.48 \\
\hline Premix vitamin ${ }^{1}$ & 2.50 & Cystine & 0.47 \\
\hline L-lysine $\mathrm{HCl}$ & 2.60 & TSAA $^{2}$ & 0.96 \\
\hline DL-methionine & 1.89 & Tryptophan & 0.18 \\
\hline L-cystine & 1.52 & AMEn $(\mathrm{kcal} / \mathrm{kg})^{3}$ & 2755 \\
\hline Total & 1000 & & \\
\hline
\end{tabular}

\footnotetext{
${ }^{1}$ Supplied per kg diet: Fe: $200 \mathrm{mg}$, Cu: $40 \mathrm{mg}$, Zn: $60 \mathrm{mg}, \mathrm{Mn}: 60 \mathrm{mg}$, Co: $0.3 \mathrm{mg}$, iodine: $0.3 \mathrm{mg}$, Se: $0.3 \mathrm{mg}$, vitamin $A: 8000 \mathrm{IU}$, vitamin $B_{6}: 3 \mathrm{mg}$, vitamin $D_{3}: 2500 \mathrm{IU}$, vitamin $B_{12}: 15 \mathrm{mcg}$, vitamin $\mathrm{E}: 30 \mathrm{mg}$, pantothenic acid: $8 \mathrm{mg}$, vitamin $B_{1}: 1.5 \mathrm{mg}$, folic acid: $0.5 \mathrm{mg}$, vitamin $B_{2}: 4 \mathrm{mg}$, biotin: $100 \mathrm{mcg}$, vitamin $\mathrm{K}_{3}: 2 \mathrm{mg}$, niacin: $20 \mathrm{mg}$, vitamin C: $100 \mathrm{mg}$, choline chloride: $500 \mathrm{mg}$

${ }^{2}$ TSAA: total sulphur amino acids

${ }^{3}$ MEn: metabolizable energy, nitrogen balanced (Phuoc et al., 2016b)
}

Experimental diets:

Treatment 1: basal diet $(B S)($ TSAA/Lys $=0.85 ;$ TSAA $=0.952 \%)(B S 100)$

Treatment 2: $90 \%$ BS (TSAA/Lys $=0.81 \% ;$ TSAA $=0.857 \%)(B S 90)$ 
Treatment 3: $80 \%$ BS (TSAA/Lys $=0.73 \% ;$ TSAA $=0.762 \%)($ BS80 $)$

Treatment 4: $110 \%$ BS (TSAA/Lys $=0.89 \% ;$ TSAA $=1.047 \%)(B S 110)$

Treatment 5: $120 \%$ BS $($ TSAA/Lys $=0.94 \& ;$ TSAA $=1.142 \%)(B S 120)$

Before formulation, the amino acid contents of feed ingredients were determined (method 999.13, AOAC, 2012) and individual amino acids were added to the experimental diets to achieve the desired TSAA/Lys ratios (Table 1 ).

Hens were offered free access to the experimental diets from 38 to 50 weeks old, with the first two weeks as an adaptation period. The experimental data were taken from the last 10 weeks of the experiments. Feed consumption, egg production and egg weight were recorded daily on a cage basis. Egg mass was calculated as egg weight multiplied by egg production. Feed conversion efficiency was calculated by dividing the average feed intake ( $\mathrm{g} / \mathrm{hen} /$ day) by grams of egg mass.

For egg quality assessment, three eggs from 10 replicates were used. Egg shape index was assessed with Vernier callipers to measure the egg length (longitudinal axis) and width (equatorial axis) (Anderson et al., 2004). The shell, yolk and white were weighed to calculate the egg components (Romanoff \& Romanoff, 1949; Abudabos, 2011). Haugh unit (HU) was calculated using Haugh's (1937) formula:

$$
\mathrm{HU}=100 \log \left(\mathrm{h}-1.7 \mathrm{w}^{0.37}+7.6\right)
$$

where: $\mathrm{HU}=$ Haugh unit

$$
\begin{aligned}
& \mathrm{h}=\text { albumen height }(\mathrm{mm}) \\
& \mathrm{w}=\text { egg weight }(\mathrm{g})
\end{aligned}
$$

The thickness of the dried eggshell without membrane was measured with a micrometre to the nearest $0.01 \mathrm{~mm}$ and was calculated as the average of three positions taken at the broad end, equator and narrow end (Saleh et al., 2016).

Feed samples were collected three times during the experimental period, stored, sub-sampled and ground, using a 1-mm screen cyclotec grinder and analysed for dry matter (DM), ash, crude protein (CP), ether extract, crude fibre, calcium and phosphorus according to AOAC (1984). Amino acids of feed ingredients were analysed by Invivo Labs, Vietnam, using the method of AOAC (2012)

An N-balance experiment was carried out before the trial ended. Two hens were housed per metabolism cage with six replicates, each cage being equipped with a plastic self-feeder and a nipple drinker. All birds were fed pelleted diets. A 48-hour collection, excreta (faeces plus urine) was recorded twice daily at 7:00 and 16:00 from trays and packed in plastic bags. Each experimental unit was identified, and the excreta were frozen at $-18{ }^{\circ} \mathrm{C}$. Prior to analysis, the excreta were homogenized and sub-sampled, then determined for DM and $\mathrm{N}$ by a macro Kjeldahl method using Vapodest -20 (990.03 AOAC, 1984).

The calculations of apparent nutrient digestibility and $\mathrm{N}$ retention were done as follows (McDonald et al., 2011)

DM digestibility (\%) = DM excreta $(\mathrm{g})^{\star} 100 / \mathrm{DM}$ feed consumed $(\mathrm{g})$

$\mathrm{N}$ excretion $(\mathrm{g})=$ excreta $(\mathrm{g}) * \mathrm{~N}$ excreta $(\%)$

$\mathrm{N}$ retention $(\%)=(\mathrm{N} \text { consumed }-\mathrm{N} \text { excreta })^{\star} 100 / \mathrm{N}$ consumed $(\mathrm{g})$

Final $N$ retention $(\%)=(N \text { consumed }(g)-N \text { egg }(g)-N \text { excreta }(g))^{\star} 100 / N$ consumed $(g)$

$\mathrm{N}$ egg $(\mathrm{g})=\mathrm{N}$ egg $(\%)^{*}$ egg mass ( $\mathrm{g} / \mathrm{hen} /$ day)

$\mathrm{N}$ retained in egg $=\mathrm{N}$ egg $(\mathrm{g}) * 100 / \mathrm{N}$ consumed

All calculations were done on a DM basis, and results were expressed per hen per day.

Data were analysed with the general linear model option of the ANOVA program in Minitab software. The model used was:

$$
Y_{i j}=\mu+T_{i}+e_{i j}
$$

where: $Y_{i j}$ is the individual observation,

$\mu$ the overall mean

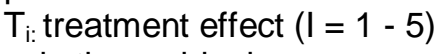

$\mathrm{e}_{\mathrm{ij}}$ is the residual error

When F-test was significant at $P<0.05$, paired comparisons were performed with Tukey's procedure. 


\section{Results and Discussion}

The TSAA/Lys ratio did not influence the intake of feed, protein, lysine or metabolizable energy (ME) (Table 2), but the intakes of methionine and TSAA increased as a result of increasing dietary methionine levels $(P<0.01)$.

The TSAA/Lys ratio did not affect egg production $(P=0.78)$, while egg weight increased as the TSAA content of the diet increased from $0.762 \%$ to $0.857 \%$. The results were similar to those of Novak et al. (2004) in that TSAA/Lys did not influence feed conversion and egg production. The authors' previous studies indicated that Ac hens fed diet of $160 \mathrm{CP} 2750 \mathrm{kcal} \mathrm{ME} / \mathrm{kg}$ of feed had similar egg production, egg weight and egg mass compared with those of $170 \star 2850$ and $180 \mathrm{~g} \mathrm{CP} * 2950 \mathrm{kcal} / \mathrm{kg}$ of feed (Phuoc et al., 2017). According to Summers et al. (1991) and Penz \& Jensen (1991), dietary CP of $16 \%$ was best for laying hens. Almeida et al. (2012) concluded that Hy-Line W-36 layers kept in hot temperature conditions and fed 2700 $\mathrm{kcal} \mathrm{ME} / \mathrm{kg}$ of feed had higher egg production and egg mass than those fed $3100 \mathrm{kcal} / \mathrm{kg}$. The requirements of CP and energy of Ac hens are therefore not exceptional.

Phuoc et al. (2018) found that the ratio of lysine/ME influenced the feed intake of Ac hens. At the level of $0.32(0.88 / 2750)$, birds consumed more feed than that of $0.43(1.18 / 2750)$, while egg production, egg weight and egg mass were higher in hens fed a ratio of 0.41 (1.12/2750 (Lys/ME). Thus, the lysine level to optimize production performance for Ac hens was higher than that recommended for commercial laying hens in a hot climate (Rao et al., 2011). The inclusion of lysine at $0.7 \%$ in the diet of Lohman brown layers increased egg production and egg mass, while at $1 \%$, hen day production was reduced and feed cost increased (Onimisi et al., 2012).

The NRC (1994) stated that commercial brown-egg layers with $100 \mathrm{~g}$ daily feed consumption need $690 \mathrm{mg}$ lysine per day. Among chicken breeds, hens with $80 \mathrm{~g}$ and $120 \mathrm{~g}$ daily feed intake require lysine concentration of $0.86 \%$ and $0.58 \%$, respectively. The two concentrations provided the same amount of 690 mg lysine per hen per day. According to NRC (1994) birds with low feed intakes required high concentrations of nutrients. However, many researchers (Scheideler et al., 1996; Novak \& Scheideler, 1998) considered that amount was not enough to enhance laying hen performance, and thought that the daily lysine intake should be between $850 \mathrm{mg}$ and $900 \mathrm{mg}$. Prochaska et al. (1996) found that egg production and egg weight were increased in hens (Hy-Line W-36) that consumed $828 \mathrm{mg}$ to $1062 \mathrm{mg}$ lysine/day. In Ac hens, which are small in size, have low feed intake, and are kept in a hot climate, Phuoc et al. (2017) found that the optimum dietary lysine concentration of $1.12 \%$ provided 700 to $750 \mathrm{mg}$ per hen per day as the hens feed ad libitum. Thus, this figure was used as a reference to control TSAA levels in formulating the experimental diets.

The present results indicated that the amounts of protein, energy and amino acid, lysine, formulated in the basal diet seemed enough for Ac hens.

The TSAA levels when increased above $10 \%$ or $20 \%$ of the basal diet were probably more than the needs of the birds. Thus egg production, egg mass and feed efficiency were not affected (Table 2). These results were similar to those reported by Alagawany \& Abou-Kassem (2014), who found that feed intake, feed efficiency, egg production and egg mass of Lohmann Brown hens were not affected by dietary methionine and lysine levels. However, Bateman et al. (2008) found that feed efficiency improved with increasing TSAA/Lys ratios.

There was a quadratic effect $(P=0.01)$ of increasing levels of TSAA on egg weight by second-order equation as follows:

Egg weight $=13.79+45.32 \mathrm{TSAA}-23.43 \mathrm{TSAA}^{2}\left(\mathrm{R}^{2}=0.92 ;\right.$ Figure 1$)$

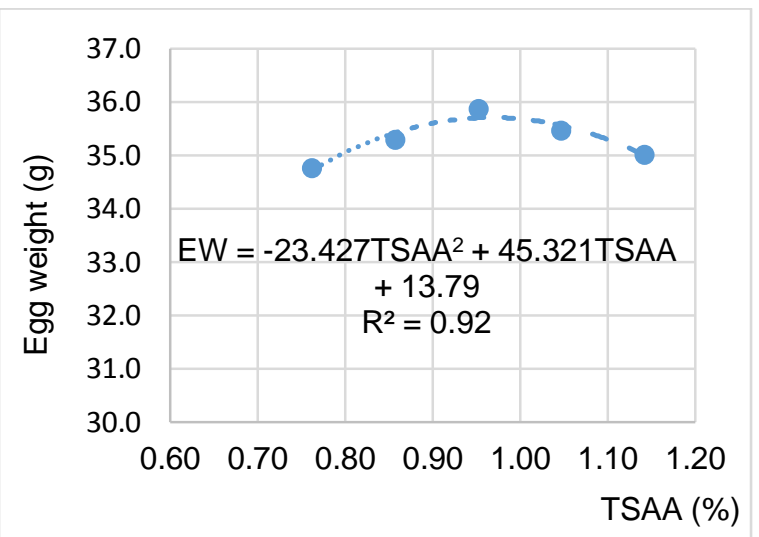

Figure 1 Effect of dietary total sulphur amino acids (TSAA)/lysine on egg weight (EW) of Ac hens 
This observation was in agreement with the finding of Harms \& Russell (2003) that increasing the methionine level above the requirements recommended by NRC (1994) produced a quadratic response in Hy-Line hens. Similarity, Fouad et al. (2016) said that increasing methionine levels did not affect egg production, but improved the egg weight and feed efficiency of ducks. Bertram et al. (1995) reported that dietary methionine improved the production performance of Leghorn laying hens. The best optimum responses of egg production, egg weight and egg mass were when TSAA levels were $0.58 \%, 0.64 \%$ and $0.61 \%$, respectively. Narváez-Solarte (2005) said that enhancing the dietary TSSA ameliorated egg production and egg weight. In a study on local Sinai laying hens, Elkloub et al. (2015) reported that dietary methionine levels did not influence egg weight, but increased egg mass.

Egg production in this study was not affected by dietary methionine and TSAA levels and indicated that TSAA intake of the basal diet was enough to maintain the egg production, egg mass and feed efficiency of Ac hens.

Saki et al. (2012) used a broken line model to estimate methionine and TSAA requirements, which showed that dietary methionnine below $0.34 \%(0.62 \%$ TSAA) reduced the egg weight of commercial laying hens. Polese et al. (2012) reported that dietary TSAA levels displayed a quadratic effect on egg weight of Shaver Brown laying hens. This response was also mentioned by Ahmad \& Roland (2003), who stated that the intake of various TSSA levels had no effect on egg production and feed conversion, but increasing TSAA levels improved egg weight of Dekalb Delta hens.

The maximum value obtained in the TSAA/Lys ratio of 0.85 , corresponds to the consumption of 319 $\mathrm{mg}$ methionine and $361 \mathrm{mg}$ TSAA/bird/day, respectively, with daily DM intake of $59.49 \mathrm{~g}$.

Although feed efficiency was not influenced by the TSAA/Lys ratio $(P=0.22)$, there was a quadratic effect $(P=0.02)$ of decreased TSAA levels:

Feed conversion efficiency $=7.653-8.625 T S A A+4.329 T S A A^{2}\left(R^{2}=0.98\right)($ Figure 2$)$.

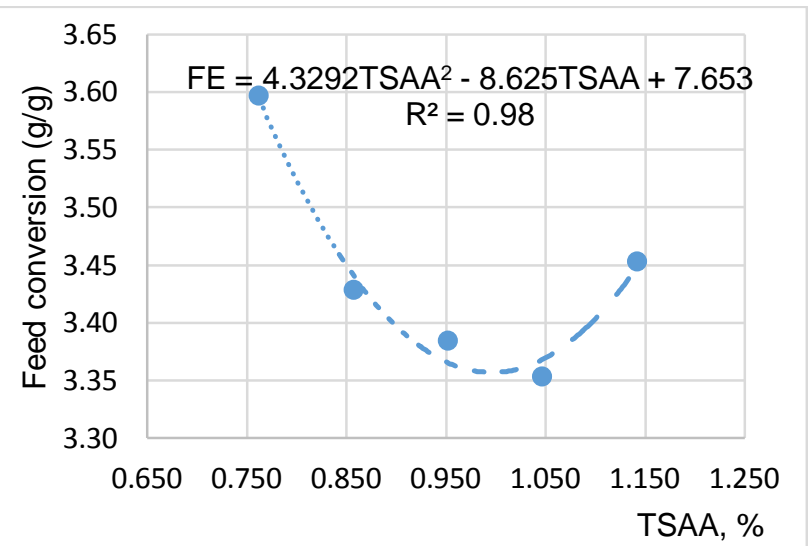

Figure 2 Effect of dietary total sulphur amino acids (TSAA) on feed conversion efficiency ( $\mathrm{g}$ feed/g egg weight)

The best feed efficiency values received, were from 3.35 to $3.39(\mathrm{~g} / \mathrm{g})$ with hens the basal and BS110 diets.

The requirements for methionine and TSAA of commercial laying hens vary widely (Wu et al., 2005; Novak et al., 2006; Domingues et al., 2012). According to Bregendahl et al. (2008), many studies on amino acid requirements had been conducted under various experimental conditions of dietary nutrient concentrations, lines or breeds and ages. These affected the amino acid requirement of hens. In 1984, the NRC recommended a daily intake of $350 \mathrm{mg}$ methionine/day, which was reduced to $300 \mathrm{mg} /$ day in 1994 . This figure was considered low for commercial laying hens (Novak et al., 2004). Ahmad \& Roland (2003) indicated that the maximum requirements for TSAA depended on environmental and market conditions.

The production of Ac chickens on the traditional small scale has low input in the form of low egg production, small-sized eggs (30 - $32 \mathrm{~g}$ ) and a slow growth rate. Ac hens stay broody for almost 21 days. This causes a decrease in egg production. Owing to market demand, Ac hens are now kept commercially. Their egg production has improved substantially because the birds are provided with more nutrients and lighting is controlled. The sitting day is reduced and is quickly disappearing. Ac hens produce approximately 200 eggs per production year. This indicates that nutrition has improved the production performance of Ac hens. 
The results in Table 2 indicate that the optimum egg weight and feed conversion responses for Ac hens were observed at $100 \%$ (BS) and $110 \%$ of dietary TSAA/Lys.

Table 2 Effect of total sulphur amino acids/lysine ratio on feed and nutrient intake and production performance of Ac hens

\begin{tabular}{|c|c|c|c|c|c|c|c|}
\hline & BS & BS90 & BS80 & BS110 & BS120 & SEM & $P$-value \\
\hline \multicolumn{8}{|l|}{ Intake (g/day) } \\
\hline Feed consumption & 66.27 & 64.23 & 66.91 & 65.78 & 65.65 & 1.12 & 0.53 \\
\hline Dry matter & 59.49 & 57.66 & 60.07 & 59.05 & 58.94 & 1.00 & 0.53 \\
\hline Crude protein & 10.63 & 10.30 & 10.73 & 10.55 & 10.53 & 0.18 & 0.53 \\
\hline Lysine & 0.743 & 0.720 & 0.750 & 0.736 & 0.737 & 0.01 & 0.53 \\
\hline Methionine & $0.319^{\mathrm{C}}$ & $0.278^{d}$ & $0.258^{d}$ & $0.380^{\mathrm{a}}$ & $0.348^{b}$ & 0.01 & 0.01 \\
\hline Methionine + cystine & $0.631^{\mathrm{c}}$ & $0.550^{d}$ & $0.510^{d}$ & $0.751^{\mathrm{a}}$ & $0.687^{b}$ & 0.01 & 0.01 \\
\hline MEn, kcal/day & 164 & 159 & 165 & 163 & 162 & 2.76 & 0.53 \\
\hline \multicolumn{8}{|l|}{ Production performance } \\
\hline Egg production (\%) & 55.47 & 53.42 & 53.80 & 55.24 & 55.41 & 1.47 & 0.78 \\
\hline Egg weight (g) & $35.87^{\mathrm{a}}$ & $35.29^{a b}$ & $34.76^{b}$ & $35.01^{a b}$ & $35.47^{\mathrm{ab}}$ & 0.22 & 0.01 \\
\hline Egg mass (g/hen/day) & 19.91 & 18.85 & 18.71 & 19.36 & 19.66 & 0.55 & 0.49 \\
\hline Feed efficient (g/g) & 3.39 & 3.43 & 3.60 & 3.45 & 3.35 & 0.08 & 0.22 \\
\hline
\end{tabular}

a,b,c,d Row means with different superscripts differ significantly at $P<0.05$

BS: basal diet; BS90: TSAA/Lys $=0.81 \%$, TSAA $=0.857 \%$; BS80: TSAA/Lys $=0.73 \%$, TSAA $=0.762 \%$; BS110: TSAA/Lys $=0.89 \%$, TSAA $=1.047 \%$ and BS120: TSAA/Lys $=0.94$, TSAA $=1.142 \%$

Lys: Iysine; TSAA: total sulphur amino acids

The TSAA/Lys ratio slightly increased the DM digestibility of the basal diet $(P=0.09)$ but did not influence the digestibility of organic matter and ether extract (Table 3).

Table 3 Effect of dietary total sulphur amino acids/lysine ratio on nutrient digestibility and nitrogen ( $N$ ) utilization

\begin{tabular}{|c|c|c|c|c|c|c|c|}
\hline & BS diet & BS80 & BS90 & BS110 & BS120 & SEM & $P$-value \\
\hline \multicolumn{8}{|l|}{ Digestibility (\%) } \\
\hline Dry matter & 73.43 & 68.66 & 67.83 & 71.44 & 71.11 & 1.49 & 0.09 \\
\hline Organic matter & 77.24 & 73.96 & 72.62 & 76.47 & 75.43 & 1.37 & 0.15 \\
\hline Ether extract & 66.88 & 59.82 & 60.72 & 62.68 & 63.64 & 3.33 & 0.61 \\
\hline \multicolumn{8}{|l|}{ Nitrogen utilization (\%) } \\
\hline N-retention ${ }^{1}$ & $52.47^{\mathrm{a}}$ & $46.87^{\mathrm{ab}}$ & $44.83^{b}$ & $51.36^{\mathrm{a}}$ & $48.85^{\mathrm{ab}}$ & 1.53 & 0.01 \\
\hline Egg nitrogen (g/day) & 0.327 & 0.318 & 0.275 & 0.263 & 0.281 & 0.02 & 0.12 \\
\hline $\mathrm{N}$ egg/N intake & 19.60 & 18.76 & 16.77 & 16.08 & 17.05 & 1.05 & 0.13 \\
\hline Final N-retention ${ }^{2}$ & 32.87 & 28.11 & 28.06 & 35.27 & 31.80 & 1.86 & 0.05 \\
\hline \multicolumn{8}{|c|}{$\begin{array}{l}{ }^{1}=\mathrm{N} \text { intake }-\mathrm{N} \text { excreta, } \\
2=\mathrm{N} \text { intake }-\mathrm{N} \text { excreta }-\mathrm{N} \text { egg, } \\
\text { a,b. Row means with different superscripts differ significantly at } P<0.05 . \\
\text { BS: basal diet; BS90: TSAA/Lys }=0.81 \%, \text { TSAA }=0.857 \% ; \text { BS80: TSAA/Lys }=0.73 \% \text {, TSAA = } 0.762 \% ; \text { BS110: } \\
\text { TSAA/Lys }=0.89 \% \text {, TSAA }=1.047 \% \text { and BS120: TSAA/Lys }=0.94, \text { TSAA }=1.142 \% . \\
\text { Lys: Iysine; TSAA: total sulphur amino acids }\end{array}$} \\
\hline
\end{tabular}



as follows:

Nitrogen retention $(\mathrm{Nr})$ was affected significantly by treatments $(P=0.01)$ with the third-order equation Nitrogen retention $=327.1-1045 x+1252 T_{S A}{ }^{2}-482 T_{S A A}^{3}\left(R^{2}=0.92 ;\right.$ Figure 3$)$.

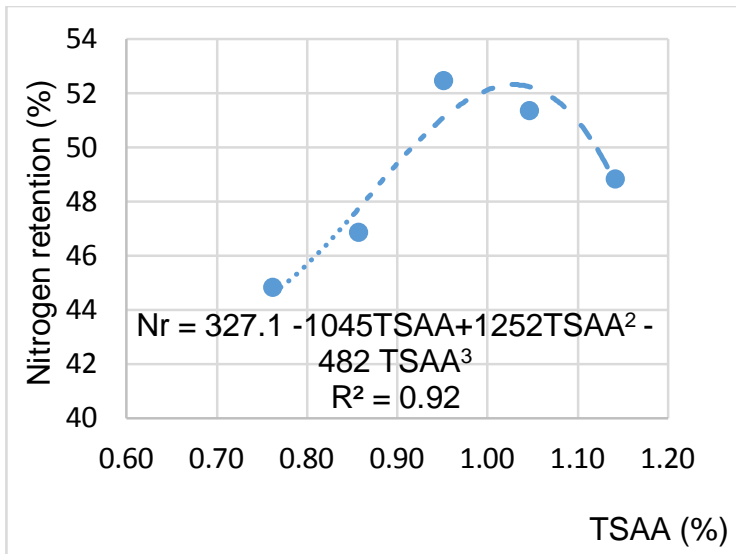

Figure 3 Effect of percentage dietary total sulphur amino acids (TSAA) on nitrogen retention (Nr)

The maximal value obtained in the TSAA/Lys ratio of 0.85 corresponds to the consumption $319 \mathrm{mg}$ methionine and $361 \mathrm{mg}$ TSAA/bird/day, with daily DM intake of $59.49 \mathrm{~g}$.

Similarity, final $\mathrm{N}$ retention was increased with increasing dietary TSAA $(P=0.05)$ as shown:

Final $N$ retention $(\mathrm{Fi} \mathrm{Nr})=813.64-2626$ TSAA $+2882.5 \mathrm{TSAA}^{2}-1035.2 \mathrm{TSAA}^{3}\left(\mathrm{R}^{2}=0.99\right.$; Figure 4).

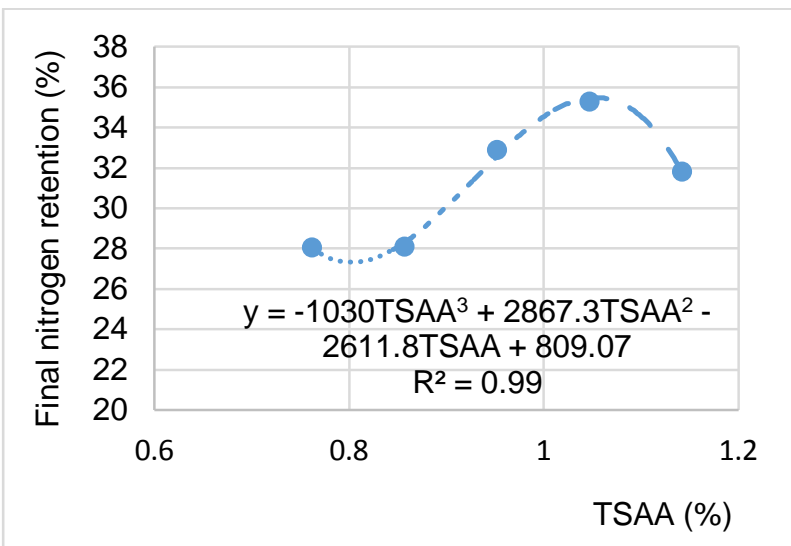

Figure 4 Effect of percentage dietary total sulphur amino acids (TSAA) on final nitrogen retention $(y)$ of Ac hens

According to Alagawany (2014), $\mathrm{N}$ retention was affected by TSAA intake, meaning that reducing dietary TSAA led to decreasing $\mathrm{N}$ excretion. The dietary methionine addition reduced $\mathrm{N}$ retention (Nonis \& Gous, 2006). In the present study, reducing dietary TSAA/Lys ratio did not cause negative effects on egg production, egg mass and feed conversion. However, increasing the TSAA/Lys ratio over $20 \%$ or reducing the BS diet by $10 \%$ to $20 \%$ led to reduced $N$ retention. To achieve both, using the average level of $0.952 \%$ of TSAA, the BS diet was more effective in term of economy.

The TSAA/Lys ratio had no effect on shade index and egg components such as albumen, yolk and shell percentage, while albumen and yolk index increased with enhancing TSAA levels (Table 4). Amaefule et al. (2004) found that methionine addition did not affect the egg quality of black Bovan Nera laying hens in the hot season. Bunchasak et al. (2012) reported that DL-methionine supplementation decreased the albumen percentage of egg. Shafer et al. (1998) concluded that albumin protein was affected by dietary methionine. An increasing albumen index could be affected by raising TSAA intake. Albumen weight 
responded with increasing methionine in the diets (Fouad et al., 2016). This present study indicated that the Haugh unit was higher in diets containing more TSAA and eggshell thickness tended to be higher as dietary TSAA increased. Narváez-Solarte et al. (2005) found an improvement in the Haugh unit as the TSAA levels in the diet reduced, but Omara \& Romeilah (2009) said that the Haugh unit was higher in hens fed diet that included $0.40 \%$ methionine compared with that of $0.35 \%$. Novak et al. (2004) did not observe any effect of digestible TSAA levels on the Haugh unit. However, many factors such as storage time, temperature and hen age could influence the internal quality of eggs (Akyurek \& Okur, 2009; Jin et al., 2011; Chung \& Lee, 2014), thus varied results were commonly found among studies.

Table 4 Effect on egg quality of dietary total sulphur amino acids to lysine ratio

\begin{tabular}{lccccccc}
\hline & BS diet & BS90 & BS80 & BS110 & BS120 & SEM & $P$ value \\
\hline Shade index & 79.56 & 77.90 & 78.54 & 78.73 & 78.52 & 0.52 & 0.28 \\
Albumen index & $0.065^{\mathrm{ab}}$ & $0.054^{\mathrm{b}}$ & $0.055^{\mathrm{b}}$ & $0.063^{\mathrm{ab}}$ & $0.07^{\mathrm{a}}$ & $<0.01$ & 0.01 \\
York index & $0.39^{\mathrm{ab}}$ & $0.36^{\mathrm{c}}$ & $0.37^{\mathrm{bc}}$ & $0.38^{\mathrm{bc}}$ & $0.41^{\mathrm{a}}$ & 0.01 & $<0.01$ \\
Albumen rate (\%) & 54.88 & 54.54 & 55.04 & 55.31 & 55.29 & 0.52 & 0.82 \\
Yolk rate (\%) & 34.14 & 34.33 & 33.76 & 33.64 & 33.53 & 0.49 & 0.74 \\
Yolk/albumen (\%) & 62.41 & 63.1 & 61.49 & 61.05 & 61.89 & 0.01 & 0.79 \\
Egg shell rate (\%) & 10.97 & 11.14 & 11.20 & 11.04 & 11.17 & 0.15 & 0.82 \\
Haugh unit & 75.99 & 71.02 & 72.13 & 74.76 & 76.95 & 1.49 & 0.03 \\
Yolk color & 6.63 & 6.13 & 6.37 & 6.80 & 6.53 & 0.18 & 0.10 \\
Egg shell thickness (mm) & 0.355 & 0.352 & 0.353 & 0.367 & 0.365 & $<0.01$ & 0.08 \\
& & & & & & & \\
\hline
\end{tabular}

${ }^{\mathrm{a}, \mathrm{b}}$ Row means with different superscripts differ significantly at $P<0.05$

BS: basal diet; BS90: TSAALys $=0.81 \%$, TSAA $=0.857 \% ;$ BS80: TSAA/Lys $=0.73 \%$, TSAA $=0.762 \% ;$ BS110: TSAA/Lys $=0.89 \%$, TSAA $=1.047 \%$ and BS120: TSAA/Lys $=0.94$, TSAA $=1.142 \%$.

Lys: lysine; TSAA: total sulphur amino acids

\section{Conclusion}

It is concluded that for Ac laying hens between 38 to 50 weeks old, optimum egg weight, feed conversion and $\mathrm{N}$ retention were obtained at the level of $0.482 \%$ methionine and $0.952 \%$ TSAA, corresponding to methionine and TSAA intake of 319 and $613 \mathrm{mg} / \mathrm{hen} /$ day, respectively. The productive performance was maximized at a TSAA/Lys ratio of 0.85 , as recommended by NRC (1994).

\section{Acknowledgements}

The authors would like to thank the Animal Science Department, Agricultural Faculty, Cantho Univeristy, Vietnam for giving them permission to use the facilities of Animal Nutrition laboratory for chemical analysis.

\section{Authors' Contributions}

TVP conducted this experiment, performing laboratory and statistical analysis as part of a PhD degree in Animal Science under the supervision of NNXD and LHM for all processes through performing the experiment to writing the manuscript.

\section{Conflict of Interest Declaration}

There is no conflict of interest with regard to this work.

\section{References}

Abudabos, A.M., 2011. Effect of enzyme supplementation and wheat middlings as an alternative to corn on laying hens performance. Ital. J. Anim. Sci.10 (4), 254-259. Doi: 10.4081/ijas.2011.e57.

Abudabos, A.M., Aljumaah, R.S., Algawaan, A.S., Al-Sornokh, H. \& Al-Atiyat, R.M., 2017. Effects of hen age and egg weight class on the hatchability of free-range indigenous chicken eggs. Braz. J. Poult. Sci. 19 (1), 033-040. http://dx.doi.org/10.1590/1806-9061-2016-0264.

Ahmad, H.A. \& Roland, D.A., 2003. Effect of environmental temperature and total sulphur amino acids on performance and profitability of laying hens: An econometric approach. J. Appl. Poult. Res. 12, 476-482. 
Akyurek, H. \& Okur, A.A., 2009. Effect of storage time, temperature and hen age on egg quality in freerange layer hens. J. Anim. Vet. Adv. 8, 1953-1958.

Alagawany, M. \& Abou-Kassem, D.E., 2014. The combined effects of dietary lysine and methionine intake on productive performance, egg component yield, egg composition and nitrogen retention in lohmann brown hens. Egyptian J. Nutrition and Feeds 17, 315-328

Almeida, V.R. Dias, A.N., Bueno, C.F.D., Couto, F.A.P., Rodrigues, P.A., Nogueira, W.C.L. \& Faria Filho, D.E., 2012. Crude Protein and Metabolizable Energy Levels for Layers Reared in Hot Climates, Braz. J. Poult. Sci. 203-208.

Amaefule, K.U., Ojewola, G.S. \& Uchegbu, E.C., 2004. The effect of methionine, lysine and/or vitamin C (ascorbic acid) supplementation on egg production and egg quality characteristics of layers in the humid tropics. Livest. Res. Rural Devel. 16, 64.

Anderson, K.E., Tharnington, J.B., Curtis, P.A., \& Jones, F.T., 2004. Shell characteristics of eggs from historic strains of single comb White Leghorn chicken and the relationship of egg shape of shell strength. Int. J. Poult. Sci. 3, 17-19.

AOAC, 1984. Official methods of analysis. 14th edition. Association of Official Analytical Chemists, Inc., Arlington, Virginia, USA.

AOAC, 2012. Official methods of analysis. 19th edition. Association of Official Analytical Chemists, Inc., Arlington, Virginia, USA

Baker, D., Batal, A., Parr, T., Augspurger, N. \& Parsons, C., 2002. Ideal ratio (relative to lysine) of tryptophan, threonine, isoleucine, and valine for chicks during the second and third weeks post hatch. Poult. Sci. 81, 485-494.

Bateman, A., Roland, D.A. \& Bryant, M., 2008. Optimal Methionine + Cysteine/Lysine ratio for first cycle phase 1 commercial Leghorns. Int. J. Poult. Sci. 7, 932-939

Bertram, H.L., Dänner, E., Jeroch, K. \& Jeroch, H., 1995. Effect of DL-methionine in a cereal-pea diet on the performance of brown laying hens. Arch. Geflugelkd. 59, 103-107.

Bregendahl, K., Roberts, S.A., Kerr, B. \& Hoehler, D., 2008. Ideal ratios of isoleucine, methionine, methionine plus cystine, threonine, tryptophan, and valine relative to lysine for White Leghorn-type laying hens of twenty-eight to thirty-four weeks of age. Poult. Sci. 87, 744-758.

Bunchasak, C., Ratchadapornvanitch, Y. \& Thiengtham, J., 2012. Comparative effects of supplemental DL-2-hydroxy-4(methylthio) butanoic acid and DL-methionine in diet on egg production and quality in laying hens. Jap. Poult. Sci. Assoc. 49, 260-267.

Chung, S.H. \& Lee, K.W., 2014. Effect of hen age, storage duration and temperature on egg quality in laying hens. Int. J. Poult. Sci. 13, 634-636.

D'Mello, J.P.F., 1993. Amino acid supplementation of cereal-based diets for non-ruminants. Anim. Feed Sci. Technol. 45 (1), 1-18

Domingues, C.H., de Sgavioli, F.S., Praes, M.F.F.M., Duarte, K.F., Castiblanco, D.M.C, Santos, E.T., Alva, J.C.R. \& Junqueira, O.M., 2012. Lysine and methionine + cystine for laying hens during the post-molting phase. Rev. Bras. Cienc. Avic. 14 (3). Campinas July/Sept. 187-192 http://dx.doi.org/10.1590/S1516-635X2012000300005

Elkloub, K., Moustafa, M.El., Beshara, M.M., Hussein, M.A.A., Kasim, M.G. \& Rehan, A.A.A., 2015. Nutritional requirements of methionine and total sulphur amino acids for local sinai laying hens during period from 42 to 58 weeks of age. Egypt. Poult. Sci. 35 (1), 423-438.

Fouad, A.M., Ruan, D., Lin, Y.C., Zheng C.T., Zhang, H.X., Chen, W., Wang, S., Xia, W.G. \& Li, Y., 2016. Effects of dietary methionine on performance, egg quality and glutathione redox system in egg-laying duck, Br. Poult. Sci. 57 (6), 818-823. Doi: 10.1080/00071668.2016.1222603

Han, Y. \& Baker, D.H., 1991. Lysine requirements of fast-and slow-growing broiler chicks. Poult. Sci. 70, $2108-2114$.

Harms, R.H. \& Russell, G.B., 2003. Performance of commercial laying hens fed diets with various levels of methionine. Appl. Poult. Res. 12, 449-455.

Haugh, R.R., 1937. The Haugh unit for measuring egg quality. US Egg Poultry Magazine 43, 522-555, $572-573$.

Jin, Y.H., Lee K.T., Lee, W.I. \& Han, Y.K., 2011. Effects of storage temperature and time on the quality of eggs from laying hens at peak production. Asian-Austral. J. Anim. Sci. 24 (2), 279-284.

Kidd, M. \& Fancher, B., 2001. Lysine needs of starting chicks and subsequent effects during the growing period. J. Appl. Poult. Res. 10, 385-393.

Kidd, M., Kerr, B., Halpin, K., McWard, G. \& Quarles, C., 1998. Lysine levels in starter and grower-finisher diets affect broiler performance and carcass traits. J. Appl. Poult. Res. 7, 351-358.

Leeson, S. \& Summers, J.D., 2005. Commercial Poultry Nutrition. 3rd edition. Nottingham University Press, Nottingham, UK.

McDonald, P., Edwards, R.A., Greenhalgh, J.F.D., Morgan, C.A., Sinclair, L.A. \& Wilkinson R.G., 2011. Animal Nutrition. 7th edition. 238-239. www.pearsoned.co.uk.

Narváez-Solarte, W., Rostango, H.S., Soares, P.R., Silva, M.A. \& Velasquez L.F.U. 2005. Nutritional requirements in methionine + cystine for white-egg laying hens during the first cycle of production. In. J. Poult. Sci. 4 (12), 965-968.

Nonis, M.K. \& Gous, R.M., 2006. Utilisation of synthetic amino acids by broiler breeder hens. S. Afr. J. Anim. Sci. 36, 126-134.

Novak, C., Yakout, H.M. \& Scheideler S.E., 2006. The effect of dietary protein level and total sulphur amino acid : Iysine ratio on egg production parameters and egg yield in Hy-Line W-98 hens. Poult. Sci. 8, 2195-2206.

Novak, C.L. \& Scheideler S.E., 1998. The combined effects of lysine and total sulphur amino acid in two strains of laying hens. Poult. Sci. 77(Suppl. 1), 102. (Abstr.)

Novak, C.L., Yakout, H. \& Scheideler, S.E., 2004. The combined effects of dietary lysine and total sulphur amino acid level on egg production parameters and egg components in Dekalb Delta laying hens. Poult. Sci. 83, 977-984. 
NRC, 1984. Nutrient requirements of poultry. 8th ed. National Academic Press, Washington, DC.

NRC, 1994. Nutrient requirements of poultry. 9th ed. Nattional Academic Press, Washington, DC.

Omara, I.I. \& Romeilah, R.M., 2009. Energy and methionine utilization in laying hen diets supplementation with folic acid. Res. J. Agric. Biol. Sci. 5 (4), 428-444.

Onimisi, P.A, Orunmuyi, M., Musa, A.A., Bale, S. \& Bawa, G.S., 2012. Effect of feed lysine content on laying hen performance and egg quality of late laying hens. Int. J. Appl. Res. Technol. 1 (5) 104-110.

Penz Jr., A.M. \& Jensen, L.S., 1991. Influence of protein concentration, amino acid supplementation, and daily time to access to high- or low-protein diets on egg weight and components in laying hens. Poult. Sci 70, 2460-2466.

Phuoc, T.V., Nguyen N.X.D. \& Manh, L.H., 2016a. Effect of protein and energy levels on performance and egg quality of black-boned layers (Ac chicken) at early first production cycle. Tropical Animal Science and Production Conference 2016 Thailand (TASP 2016). 26-29 July 2016. p 209-213.

Phuoc, T.V., Nguyen, N.X.D \& Manh, L.H., 2016b. Determination and predictation of metabolizable energy concentration in ingredients fed Ac chicken. J. Anim. Hus. Sci. Technol. 8 (16), 41-46. (in Vietnamese)

Phuoc, T.V., Nguyen, N.X.D. \& Manh, H.M., 2017. Effect of dietary protein and energy on egg production, quality and nitrogen utilization of ac layers. National Conference Animal and veterinary Sciences March $11^{\text {th }}$ and $12^{\text {th }} 2017$ Cantho Univeristy, pp. 169-178. (in Vietnamese)

Phuoc, T.V., Nguyen N.X.D. \& Luu, H.M., 2018. Effects of dietary lysine to energy ratios on reproductive performance, egg quality, nitrogen utilization and blood parameters of Ac Layers. J. Agri. Sci. Rural. Develop. 10, 94-103. (in Vietnamese)

Phuong, T.T.M. \& Thien, N.V., 2008. Ac Chicken production in Vietnam. 7th RBI Gobal Conference on the Conversion of Animal Genetic Resources, Impact of Globalisation on Animal Genetic Resource,' Hanoi, Vietnam, 14-18 September 2008.

Polese, C., Vianna, N., Garcia, C., Bartolomeu, M.A., Takahashi, S.E. \& Vilela, V.O., 2012. Nutritional levels of digestible methionine + cystine to brown-egg laying hens from 50 to 66 weeks of age. R. Bras. Zootec. 41 (7), 1691-1698.

Prochaska, J.F., Carey, J.B. \& D.J., 1996. The effect of L-lysine intake on egg component yield and composition in laying hens. Poult. Sci. 75, 1268-1277.

Rao, R.S., Ravindran, V., Srilatha, T., Panda, A.K. \& Raju, M.V.L.N., 2011. Effect of dietary concentrations of energy, crude protein, lysine, and methionine on the performance of White Leghorn layers in the tropics. J. Appl. Poult. Res. 20 (4), 528-54. https://doi.org/10.3382/japr.2011-00355

Romanoff, A.L. \& Romanoff, A.J., 1949. The Avian Egg. John Wiley \& Sons, New York.

Saki, A.A., Naseri, H.R., Tabatabaei, M.M., Zamani, P. \& Haghight, M., 2012. Estimates of methionine and sulphur amino acid requirements for laying hens using different models. Braz. J. Poult. Sci. 14 (3), 159-232.

Saleh, A.A., Gálik, B., Arpášová, H., Capcarová, M., Kalafová, A., Šimko, M., Juráček, M., Rolinec, M., Bíro, D. \& Abudabos, A.M., 2016. Synergistic effect of feeding Aspergillus awamori and lactic acid bacteria on performance, egg traits, egg yolk cholesterol and fatty acid profile in laying hens. Ital. J. Anim. Sci. 16 (1), 132-139.

Scheideler, S.E., Novak, C., Sell, J.L. \& Douglas, J., 1996. Hisex White Leghorn lysine requirement for optimum body weight and egg production during early lay. Poult. Sci. 75(Suppl. 1), 86. (Abstr.)

Shafer, D.J., Carey, J.B., Prochaska, J.F. \& Sams, A.R., 1998. Dietary Methionine intake effects on egg component yield, composition, functionality and texture profile analysis. Poult. Sci. 71, 1056-1062.

Sohail, S.S., Bryant, M.M. \& Roland, D.A., 2002. Influence of supplemental lysine, isoleusine, threonine, tryptophan and total sulfur amino acids on egg weight of Hy-line W36 hens. Poult. Sci. 81 (7), 1038-1044.

Summers, J.D., Atkinson, J.L. \& Spratt, D., 1991. Supplementation of a low protein diet in an attempt to optimize egg mass output. Can. J. Anim. Sci., 71, 211-220

Tesseraud, S., Peresson, R. \& Chagneau, A.M., 1996. Dietary lysine deficiency greatly affects muscle and liver protein turnover in growing chickens. Br. J. Nutr. 75, 853-865.

Tesseraud, S., Larbier, M., Chagneau, A.M. \& Geraert, P.A., 1992. Effects of dietary lysine on muscle protein turnover in growing chickens. Reprod. Nutr. Dev. 32, 163-175.

Waibel, P.E., Carlson, C.W., Brannon, J.A. \& Noll, S.L., 1995. Replacing protein in corn-soybean turkey diets with methionine and lysine. Poult. Sci. 74, 1143-1158.

Wu, G., Bryant, M.M. \& Roland, D.A., 2005. Effect of synthetic lysine on performance of commercial leghorns in phase 2 and 3 (second cycle) while maintaining the methionine + cysteine/lysine ratio at 0.75 (abstract). Poult. Sci. 84 (Supplement 1), 43.

Yuan, Y., Zhao, X., Zhu, Q., Li, J, Yin, H., Gilbert, E.R, Zhang, Y., Liu, Y., Wang, Y., Li, D., Yang, Z. \& Shu, G., 2015. Effects of dietary lysine levels on carcass performance and biochemical characteristics of Chinese local broilers. Ital. J. Anim. Sci. 14, 461-465. 